\title{
Inhibitory Effects of Bangladeshi Medicinal Plant Extracts on Interactions between Transcription Factors and Target DNA Sequences
}

\author{
Ilaria Lampronti ${ }^{1}$, Mahmud T. H. Khan ${ }^{2}$, Monica Borgatti ${ }^{1}$, Nicoletta Bianchi ${ }^{1}$ and \\ Roberto Gambari ${ }^{1,3,4}$
}

${ }^{1}$ ER-GenTech, Department of Biochemistry and Molecular Biology, University of Ferrara, Italy, ${ }^{2}$ University of Science and Technology of Chittagong, Bangladesh, ${ }^{3}$ Laboratory for the Development of Pharmacologic and Pharmacogenomic Therapy of Thalassemia, Biothecnology Center and ${ }^{4}$ Center of Excellence on Inflammation, University of Ferrara, Italy

\begin{abstract}
Several transcription factors (TFs) play crucial roles in governing the expression of different genes involved in the immune response, embryo or cell lineage development, cell apoptosis, cell cycle progression, oncogenesis, repair and fibrosis processes and inflammation. As far as inflammation, TFs playing pivotal roles are nuclear factor kappa B (NF-kB), activator protein (AP-1), signal transducer and activator of transcription (STATs), cAMP response element binding protein (CREB) and GATA-1 factors. All these TFs regulate the expression of proinflammatory cytokines and are involved in the pathogenesis of a number of human disorders, particularly those with an inflammatory component. Since several medicinal plants can be employed to produce extracts exhibiting biological effects and because alteration of gene transcription represents a very interesting approach to control the expression of selected genes, this study sought to verify the ability of several extracts derived from Bangladeshi medicinal plants in interfering with molecular interactions between different TFs and specific DNA sequences. We first analyzed the antiproliferative activity of 19 medicinal plants on different human cell lines, including erythroleukemia K562, B lymphoid Raji and T lymphoid Jurkat cell lines. Secondly, we employed the electrophoretic mobility shift assay as a suitable technique for a fast screening of plant extracts altering the binding between NF-kB, AP-1, GATA-1, STAT-3, CREB and the relative target DNA elements.
\end{abstract}

Keywords: AP-1 - CREB - GATA-1 - gene expression - medicinal plants - NF-kB - STAT-3 transcription factors

\section{Introduction}

Transcription factors (TFs) play key roles in the regulation of gene expression (1). Accordingly targeting of TFs with DNA-based molecules (2,3) or low-molecular weight compounds $(4,5)$ might be of great interest to

For reprints and all correspondence: Roberto Gambari, Department of Biochemistry and Molecular Biology, University of Ferrara, Via Fossato di Mortara, 74, 44100-Ferrara Italy. Tel: +39 0532 424443; Fax: +390532 424500; E-mail: gam@unife.it develop selective molecules exhibiting therapeutic potential in several human pathologies (6-8). One of the best examples of the interplay between TFs, gene expression, drug design and discovery and novel therapeutic approaches is inflammation. Several TFs are indeed involved in inflammatory processes, including Nuclear Factor-kappa B (NF-kB) (9-14), activator protein 1 (AP-1) (15-17), signal transducer and activator of transcription (STATs) (18), cAMP response element binding protein (CREB) (19) and GATA-1 factors $(20,21)$. 
All these TFs have been described to play a significant role in regulating expression of genes coding proinflammatory cytokines and in the pathogenesis of a large number of human disorders, particularly those characterized by a chronic inflammatory component (17). These include rheumatoid arthritis $(22,23)$, chronic asthma $(24,25)$, diabetes mellitus type 1 (26) and Crohn's disease (27).

With respect to anti-inflammatory activities, several plant-derived compounds exhibit significant effects (28-33). Therefore, medicinal plants represent a potential source of molecules of significant relevance for developing novel drugs, especially designed for treating and/or controlling chronic inflammatory conditions. Despite the therapeutic effects of medicinal plant extracts that are well-known and reviewed in several articles (34-44), sparse information is available on their effects on activity of TFs $(45,46)$.

The main concern here was to screen Bangladeshi medicinal plants for their activity in inhibiting the interactions between nuclear factors and double stranded target oligonucleotides mimicking the NF-kB, AP-1, STAT-3, CREB and GATA-1 binding sites. To this aim, electrophoretic mobility shift assay (47) has been employed. Extracts from several medicinal plants have been considered, including Emblica officinalis, Aegle marmelos, Moringa oleifera, Terminalia arjuna, Vernonia anthelmintica, Oroxylum indicum, Saraca asoka, Rumex maritimus, Lagerstroemia speciosa, Red sandal, Cuscuta reflexa, Argemone mexicana, Hemidesmus indicus, Polyalthia longifolia, Cassia sophera, Paederia foetida, Hygrophilla auriculata, Ocimum sanctum and Aphanamixis polystachya.

\section{Methods}

\section{Plant Materials and Extraction}

The following plant material was extracted with absolute ethanol in cold extraction process: (i) the stem bark of C. sophera $($ yield $=10.22 \%), T$. arjuna (yield $=10.1 \%$ ), $O$. indicum (yield $=11.0 \%$ ), A. marmelos (yield $=12.25 \%$ ), S. asoka (yield $=14.16 \%)$, Red Sandal (yield $=13.2 \%$ ), the dried leaves of $O$. sanctum (yield $=3.22 \%$ ), the dried whole plant of $C$. reflexa (yield $=15.03 \%$ ) and $P$. foetida Linn. (yield $=11.92 \%$ ). The seeds of $H$. auriculata were extracted with $80 \%$ ethanol:water in cold extraction process (yield $=1.15 \%$ ). The dried whole plant of $L$. speciosa was first defatted with petroleum ether and then extracted with chloroform and the yield was $7.1 \%$. The roots of $H$. indicus Linn (yield $=8.9 \%$ ), the stem barks of $P$. longifolia (Sonn.) (yield $=6.87 \%$ ), the seed of $V$. anthelmintica (yield $=15.24$ ) and the stem barks of A. polystachya Wall \& Parker were extracted with $80 \%$ ethanol:water in cold extraction process. The extraction of $A$. polystachya resulted in two extracts, an oily phase and a solid mass, with a yield of $2.54 \%$ and $8.91 \%$, respectively. The roots of $M$. oleifera Lamk. were extracted with absolute ethanol in a cold extraction process. This crude extract (yield $=14.54 \%$ ) was further partitioned with $n$-hexane (yield $=7.39 \%$ ), chloroform (yield $=5.94 \%$ ), methanol (yield $=9.46 \%$ ) and water (yield $=9.48 \%$ ). The dried fruits of E. officinalis were extracted with absolute ethanol (yield $=9.33 \%$ ). This ethanolic extract was defatted with petroleum ether and the defatted extract was successively fractionated with different solvent systems on the basis of polarity. The solvents were $100 \%$ dichloromethane, $25 \%$ ethylacetate-dichloromethane, $50 \%$ ethylacetatedichloromethane, $75 \%$ ethylacetatedichloromethane, $100 \%$ ethylacetate, butanol and acetone and the remaining aqueous portions were separated. The dried whole plant of $R$. maritimus was first extracted with methanol (yield $=11.21 \%$ ), then defatted with petroleum ether (yield $=9.87$ ) and successively extracted with chloroform, ethylacetate and methanol (yield = 8.7). The whole plant of A. mexicana were extracted with methanol (yields $=1.25 \%$ ).

\section{Cell Lines, Culture Conditions and Assays of in vitro Antiproliferative Activity}

Human erythroleukemia K562 (48), B lymphoid Raji (49) and $\mathrm{T}$ lymphoid Jurkat (50) cells were maintained in RPMI 1640 (Flow Laboratories, Irvine, UK) at $37^{\circ} \mathrm{C}$ in a humidified 5\% $\mathrm{CO}_{2}$ atmosphere, supplemented with $10 \%$ fetal bovine serum (FBS; CELBIO, Milano, Italy), 100 units $/ \mathrm{ml}$ penicillin and $100 \mu \mathrm{g} / \mathrm{ml}$ streptomycin (Aldrich, St.Louis, MA, USA). For analyzing the effects on in vitro cell growth, cells were seeded at the initial cell concentration of $30000 \mathrm{cells} / \mathrm{ml}$, cultured in the absence or presence of plant extracts and the cell number $/ \mathrm{ml}$ determined using a model ZBI Coulter Counter (Coulter Electronics, Hialeah, FL, USA) after 2, 3, 4, 5 days of cell culture. The $\mathrm{IC}_{50}$ values (i.e. the concentrations of extracts leading to $50 \%$ inhibition of cell growth, when treated cells are compared with untreated, control cultures) were determined in order to compare the activities of the different extracts. $\mathrm{IC}_{50}$ was determined usually after 4 days, when untreated cells are in the $\log$ phase of cell growth.

\section{Electrophoretic Mobility Shift Assay (EMSA)}

Electrophoretic mobility shift assay was performed by using double stranded ${ }^{32} \mathrm{P}$-labeled oligonucleotides as target DNA. Binding reactions were set up as described elsewhere in binding buffer $(10 \%$ glycerol, $0.05 \%$ NP-40, $10 \mathrm{mM}$ Tris- $\mathrm{HCl} \mathrm{pH} 7.5,50 \mathrm{mM} \mathrm{NaCl}$, $0.5 \mathrm{mM}$ DTT, $\left.10 \mathrm{mM} \mathrm{MgCl}_{2}\right)$, in the presence of poly(dI:dC).poly(dI:dC) (Pharmacia, Uppsala, Sweden), $2-5 \mu \mathrm{g}$ of crude nuclear extracts and $0.25 \mathrm{ng}$ of labeled 
oligonucleotide, in a total volume of $20 \mu 1(46,47)$. After $30 \mathrm{~min}$ binding at room temperature samples were electrophoresed at constant voltage $(200 \mathrm{~V}$ for $1 \mathrm{~h})$ through a low ionic strength $(0.25 \times \mathrm{TBE}$ buffer $)$ $(1 \times \mathrm{TBE}=0.089 \mathrm{M}$ Tris-borate, $0.002 \mathrm{M}$ EDTA $)$ on $6 \%$ polyacrylamide gels until tracking dye (bromophenol blue) reached the end of a $16 \mathrm{~cm}$ slab. Gels were dried and exposed for autoradiography with intensifying screens at $-80^{\circ} \mathrm{C}$. In these experiments, DNA/ protein complexes migrate through the gel with slower efficiency. In studies on the inhibitors of protein/DNA interactions, addition of the reagents was as follows: (i) $\operatorname{poly}(\mathrm{dI}: \mathrm{dC}) \cdot \operatorname{poly}(\mathrm{dI}: \mathrm{dC})$; (ii) labeled oligonucleotides mimicking the binding sites for TFs to be modulated; (iii) plant extracts; (iv) binding buffer; (v) nuclear factors. The nucleotide sequences of double-stranded target DNA utilized in these experiments were $5^{\prime}$-CGC TGG GGA CTT TCC ACG G-3' (sense strand, NF-kB), 5'-CGC TTG ATG AGT CAG CCG GAA-3' (AP-1), 5'-CAC TTG ATA ACA GAA AGT GAT AAC TCT-3' (GATA-1), 5'-CTG ATT TCC CCG AAA TGA CGG -3' (STAT-3) and 5'-TTG AAT GAC GTC AAG GCC-3' (CREB). The synthetic oligonucleotides utilized in this study were purchased from Sigma Genosys (Sigma Genosys, Cambs, UK). For quantitative determinations, the bands corresponding to protein-DNA complexes were analyzed using the BIO-RAD Gel Doc 2000 (Bio-Rad Laboratories). The values obtained in the reactions performed in the presence of plant extracts were compared with control untreated reactions.

\section{Results}

\section{Differential Inhibitory Effects of Extracts of Bangladeshi Medicinal Plants on in vitro Proliferation of Human Tumor Cell Lines}

In order to obtain preliminary information on the biological properties of the employed extracts, their effects on cell growth were examined. The extracts isolated from E. officinalis, A. marmelos, $M$. oleifera, T. arjuna, $V$. anthelmintica, $O$. indicum, $S$. asoka, R. maritimus, L. speciosa, Red sandal, C. reflexa, A. mexicana, H. indicus, $P$. longifolia, C. sophera, $P$. foetida, $H$. auriculata, $O$. sanctum and $A$. polystachya were first tested as potential inhibitors of in vitro proliferation of human erythroleukemic K562 cells. Figure 1 shows some representative results on the effects of increasing amounts of plant extracts on proliferation of K562 cells. The complete set of results is shown in Table 1, which summarizes the data derived from four independent experiments. The highest antiproliferative activity was found using extracts from E. officinalis $\left(\mathrm{IC}_{50}=0.75 \pm 0.04\right.$ and $0.51 \pm 0.08 \mu \mathrm{g} / \mathrm{ml}$ from unfractionated and $n$-butanolic extracts, respectively $), \quad O . \quad$ indicum $\quad\left(\mathrm{IC}_{50}=3.77 \pm 0.32 \mu \mathrm{g} / \mathrm{ml}\right)$,

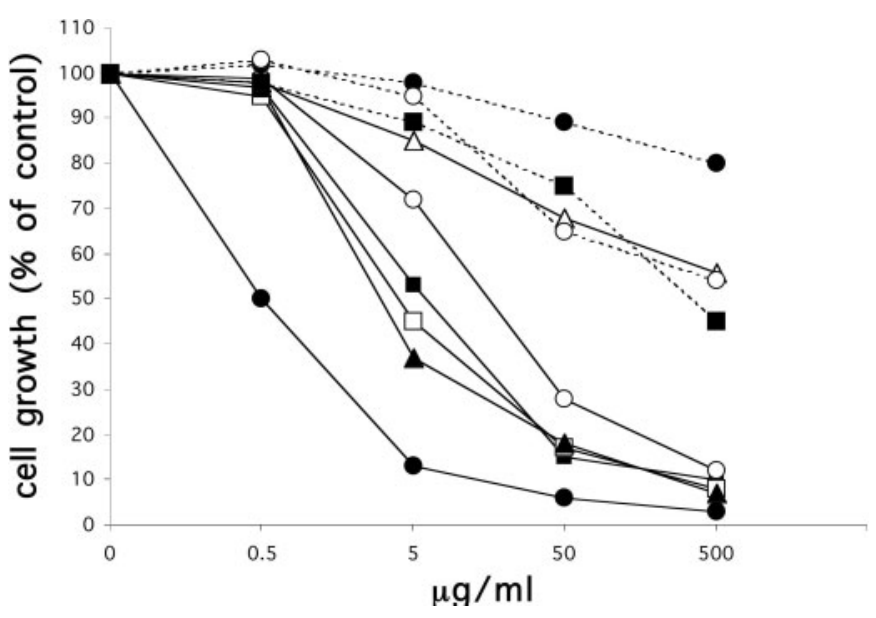

Figure 1. Effects of extracts from medicinal plants on K562 cell proliferation. K562 cells were seeded at the initial cell concentration of 30000 cells $/ \mathrm{ml}$ and then cultured for 7 days in the presence of the indicated amounts of $n$-butanol extracts from $E$. officinalis (black circles, solid line), M. oleifera (black squares, solid line), tetrachloromethane fraction of A. marmelos (white circles, solid line), T. arjuna (white squares), O. indicum (black triangles), H. indicus (white triangles), $P$. foetida (black circles, dotted line), H. auriculata (white circles, dotted line) and $C$. sophera (black squares, dotted line).

Table 1. Antiproliferative effects of different extracts derived from Bangladeshi medicinal plants on erythroleukemic K562 cells

\begin{tabular}{lc}
\hline Medicinal plant & $\mathrm{IC}_{50}(\mu \mathrm{g} / \mathrm{ml})$ \\
\hline E. officinalis (unfractionated extract) & $0.75 \pm 0.04$ \\
E. officinalis ( -butanolic extract) & $0.51 \pm 0.08$ \\
A. marmelos (ethyl acetate fraction) & $135.50 \pm 17.54$ \\
A. marmelos (petroleum ether fraction) & $8.30 \pm 0.99$ \\
A. marmelos (tetrachloromethyl fraction) & $30.25 \pm 2.76$ \\
M. oleifera & $6.88 \pm 6.05$ \\
T. arjuna & $4.45 \pm 0.50$ \\
V. anthelmintica & $66.84 \pm 1.64$ \\
O. indicum & $3.77 \pm 0.32$ \\
S. asoka & $48.50 \pm 12.02$ \\
R. maritimus (acqueous fraction) & $39.94 \pm 4.43$ \\
R. maritimus (methanolic fraction) & $303.80 \pm 118.44$ \\
L. speciosa & $46.00 \pm 6.01$ \\
Red sandal & $36.94 \pm 5.88$ \\
C. reflexa & $115.67 \pm 47.14$ \\
A. mexicana & $59.56 \pm 6.65$ \\
H. indicus & $626.76 \pm 93.99$ \\
P. longifolia & $212.63 \pm 20.04$ \\
C. sophera & $483.88 \pm 134.42$ \\
P. foetida & $799.54 \pm 44.49$ \\
H. auricolata & $523.77 \pm 23.89$ \\
O. sanctum & $67.01 \pm 2.24$ \\
A. polystachia (solid fraction) & $41.06 \pm 0.02$ \\
A. polystachia (oil fraction) & $91.50 \pm 17.76$ \\
\hline & \\
The & \\
A &
\end{tabular}

The reported data represent the concentrations (average $\pm S D$ of four independent experiments) of plant extracts leading to a $50 \%$ inhibition of cell growth. 

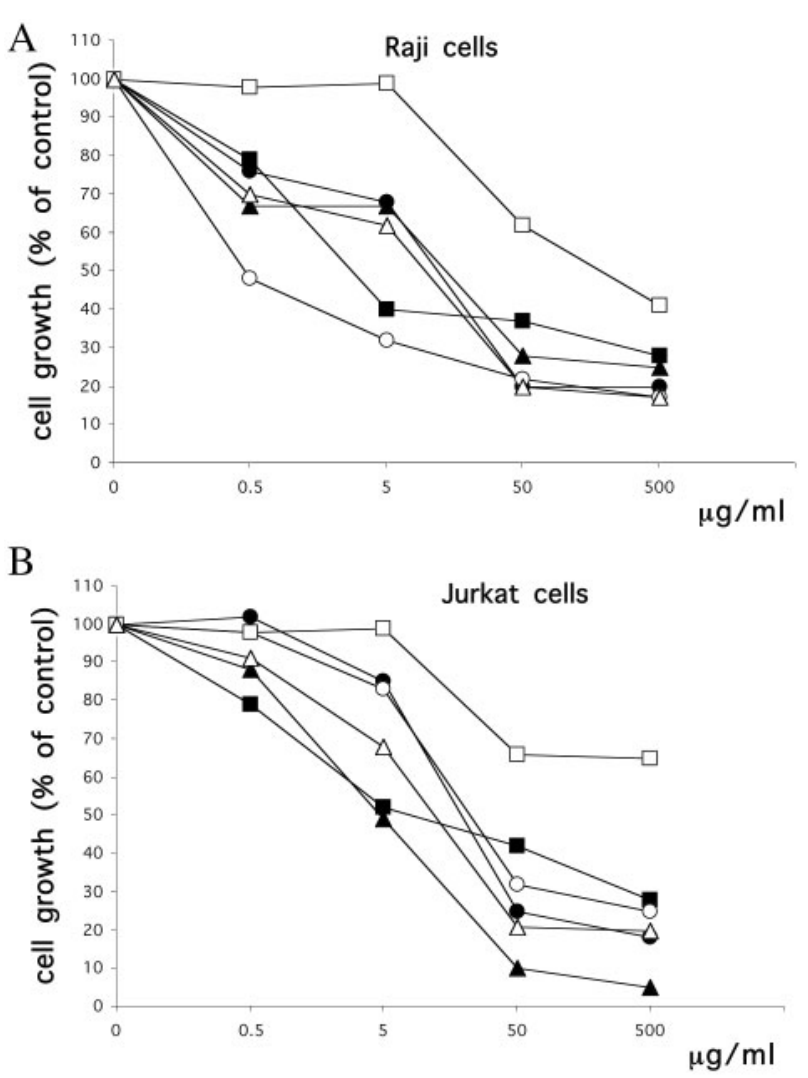

Figure 2. Inhibitory effects of extracts from E. officinalis (unfractionated extracts, black circles; $n$-butanolic extracts, white triangles), $O$. indicum (black triangles), T. arjuna (white squares), M. oleifera (black squares) and A. marmelos (petroleum ether fraction, white circles) on proliferation of Raji (panel A) and Jurkat (panel B) cell lines. Cells were seeded at the initial cell concentration of $30000 \mathrm{cells} / \mathrm{ml}$ and then cultured for 7 days in the presence of the indicated amounts of extracts.

Table 2. Antiproliferative activity $\left(\mathrm{IC}_{50}, \mu \mathrm{g} / \mathrm{ml}\right)$ of extracts of E. officinalis, A. marmelos, M. oleifera, T. arjuna and $O$. indicum on Raji and Jurkat cell lines

\begin{tabular}{lcl}
\hline Medicinal plant & Raji cells & Jurkat cells \\
\hline E. officinalis (unfractionated extract) & $24.43 \pm 9.4$ & $33.28 \pm 6.2$ \\
E. officinalis ( -butanolic extract) & $17.93 \pm 8.0$ & $10.77 \pm 6.1$ \\
A. marmelos (petroleum ether fraction) & $0.30 \pm 0.1$ & $35.25 \pm 3.8$ \\
M. oleifera & $1.82 \pm 0.2$ & $18.00 \pm 2.0$ \\
T. arjuna & $63.00 \pm 5.0$ & $>500.00$ \\
O. indicum & $23.20 \pm 9.6$ & $4.11 \pm 0.1$ \\
\hline
\end{tabular}

The reported data represent the concentrations (average $\pm S D$ of four independent experiments) of plant extracts leading to a $50 \%$ inhibition of cell growth.

T. arjuna $\left(\mathrm{IC}_{50}=4.45 \pm 0.50 \mu \mathrm{g} / \mathrm{ml}\right), \quad$ A. marmelos $\left(\mathrm{IC}_{50}=8.30 \pm 0.99 \mu \mathrm{g} / \mathrm{ml}\right.$, petroleum ether fraction $)$ and $M$. oleifera $\left(\mathrm{IC}_{50}=16.88 \pm 6.05 \mu \mathrm{g} / \mathrm{ml}\right)$. The other tested plant extracts displayed lower antiproliferative activity (Table 1 ).

The most active plant extracts on K562 cells were also tested on B lymphoid Raji and T lymphoid Jurkat human tumor cell lines. Figure 2 shows the effects on cell growth of Raji and Jurkat cells treated with increasing amounts of the extracts. Table 2 shows the $\mathrm{IC}_{50}$ values obtained for each cell line. The obtained data indicate that these plant extracts, despite some differences, inhibit the in vitro proliferation of all analyzed human tumor cell lines.

These results confirm and further extend the list of analyzed compounds previously published on the antiproliferative activity of $E$. officinalis (35), A. marmelos (37), V. anthelmintica, O. indicum, A. mexicana (39).

\section{Identification of Plant Extracts Exhibiting High Levels of Inhibitory Activity on Protein-DNA Interactions}

To determine whether inhibitory activities against TFs/DNA interactions are present in extracts from medicinal plants, the same plant extracts that were tested for antiproliferative activity were assayed for their ability in inhibiting the interactions between nuclear factors isolated from the human leukemic K562 cells and double stranded target oligonucleotides that mimic the binding sites of the NF-kB, AP-1, GATA-1, STAT-3 and CREB TFs.

Representative results are shown in Figs. 3-6 and summarized in Table 3. The electrophoretic mobility shift assay was performed using $\left[\gamma_{-}{ }^{32} \mathrm{P}\right] 5^{\prime}$-end-labeled oligonucleotides. The 5'-labeled oligonucleotides were incubated with plant extracts for $15 \mathrm{~min}$ and then nuclear extracts were added. After $15 \mathrm{~min}$ binding at room temperature, the samples were electrophoresed. The gels were dried and subjected to standard autoradiographic procedures.

As far as the inhibitory effects on NF-kB/DNA interactions (Figs. 3 and 4), the results show that high activity was exhibited by E. officinalis, ethyl acetate and petroleum ether fractions of $A$. marmelos, M. oleifera, $V$. anthelmintica, aqueous and methanolic fractions of $R$. maritimus, L. speciosa, H. indicus, P. longifolia, T. arjuna, S. asoka and solid and oil fractions of A. polystachya. On the contrary, high concentrations of extracts from $O$. indicum, Red sandal, C. reflexa, A. mexicana, C. sophera, P. foetida, H. auriculata and $O$. sanctum were unable to inhibit NF-kB/DNA interactions. In conclusion, when Figs 3 and 4 and Table 3 are considered together, the highest effects against NF-kB activity were displayed by $T$. arjuna, $S$. asoka and A. polystachya.

Terminalia arjuna, S. asoka and A. polystachya (solid fraction) are the most effective extracts inhibiting also AP-1/DNA interactions (Fig. 5A). Extracts showing a moderate inhibitory activity instead were derived from $M$. oleifera and aqueous fraction of $R$. maritimus. A lower activity was characterized by E. officinalis, A. marmelos, $O$. indicum, L. speciosa, $H$. indicus and oil fraction of $A$. polystachya. The other extracts were inactive. 

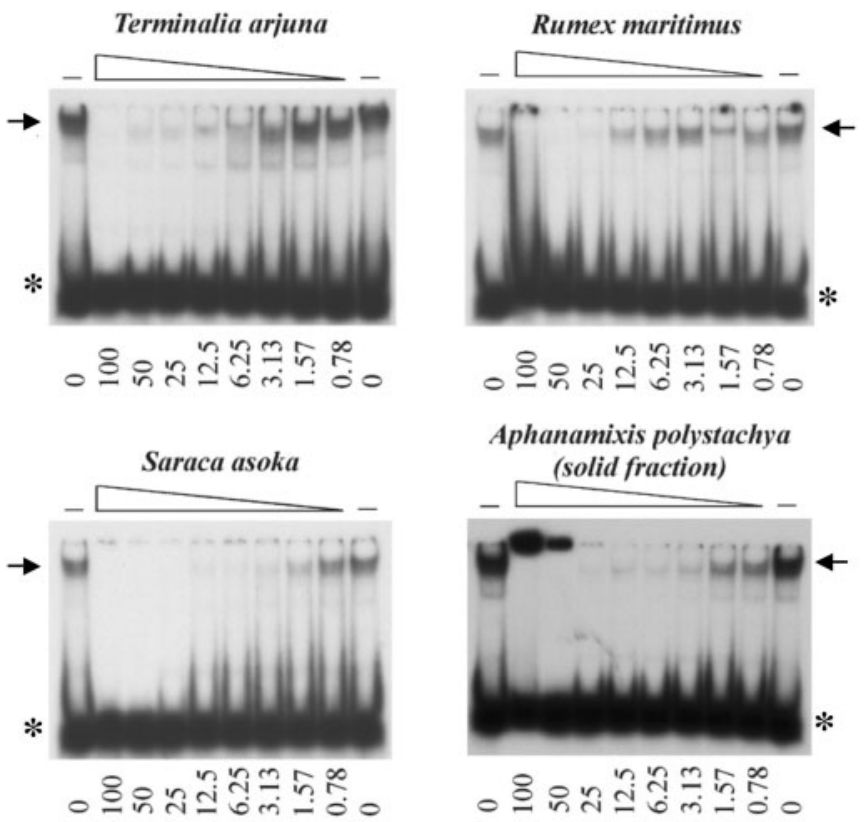

Emblica officinalis
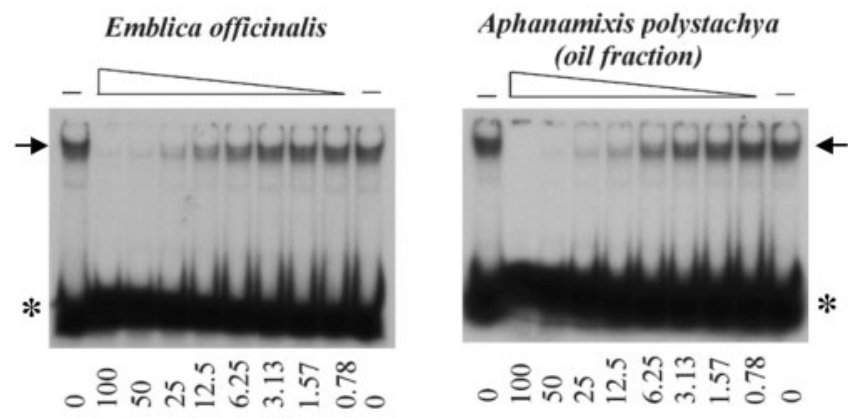

$\mu \mathrm{g} /$ binding reaction

Figure 3. Extracts from medicinal plants differentially inhibit molecular interactions between NF-kB and target DNA sequences. The effects on NF-kB/DNA interactions of the indicated amounts of extracts ( $\mu \mathrm{g} /$ binding reactions) from $T$. arjuna, $R$. maritimus (aqueous extract), S. asoka, E. officinalis and A. polystachia (solid and oil fractions) were studied by EMSA. The addition of the reagents in the $20 \mu$ l binding reactions was as follows: (i) poly(dI:dC).poly(dI:dC); (ii) labeled oligonucleotides mimicking the binding sites for TFs to be assayed; (iii) plant extracts; (iv) binding buffer; (v) nuclear factors. After 30 min binding, samples were electrophoresed on $6 \%$ polyacrylamide gels, that were then dried and autoradiographed. ${ }^{*}=$ free probe; arrows $=\mathrm{NF}-\mathrm{kB} /$ DNA complexes.

Terminalia arjuna was also the most active extract on inhibition of interaction between GATA-1 and DNA. As far as inhibition of GATA-1/DNA interaction, petroleum ether fraction of $A$. marmelos, $R$. maritimus aqueous fraction, S. asoka, A. polystachya solid fraction, $M$. oleifera, $V$. anthelmintica and $L$. speciosa extracts were efficient (Fig. 5B). Emblica officinalis extracts showed a intermediate activity, whereas $100 \mu \mathrm{g} /$ binding reaction of extracts from $A$. marmelos, $R$. maritimus methanolic fraction, Red sandal, C. reflexa, A. mexicana, $H$. indicus, C. sophera, $P$. foetida, H. auriculata,
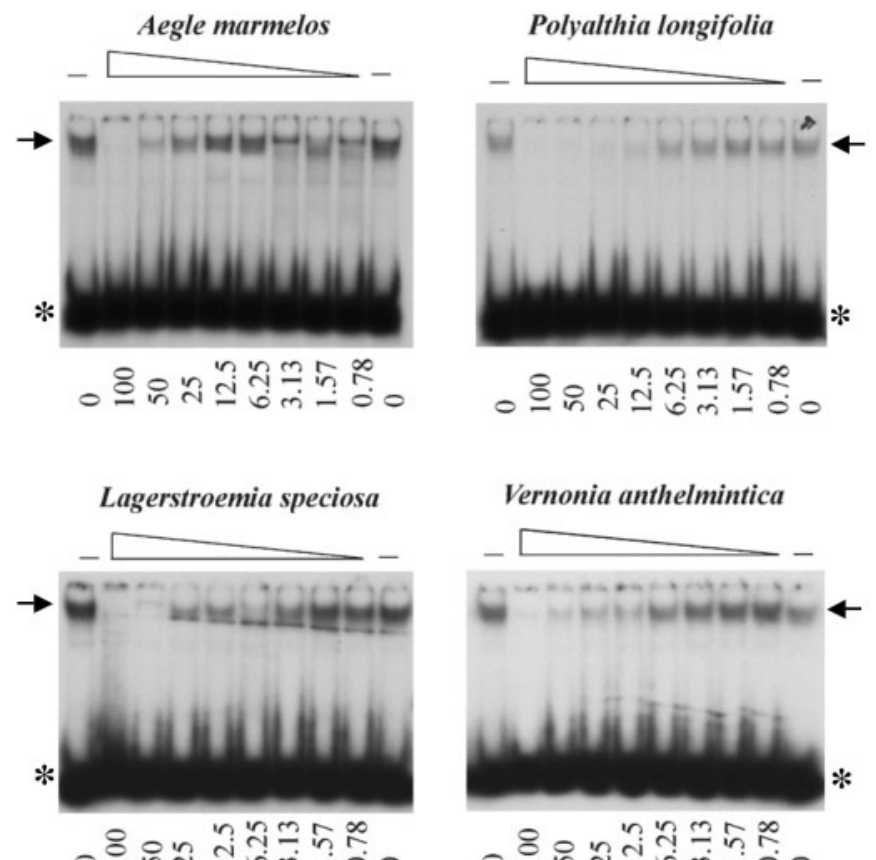

Vernonia anthelmintica
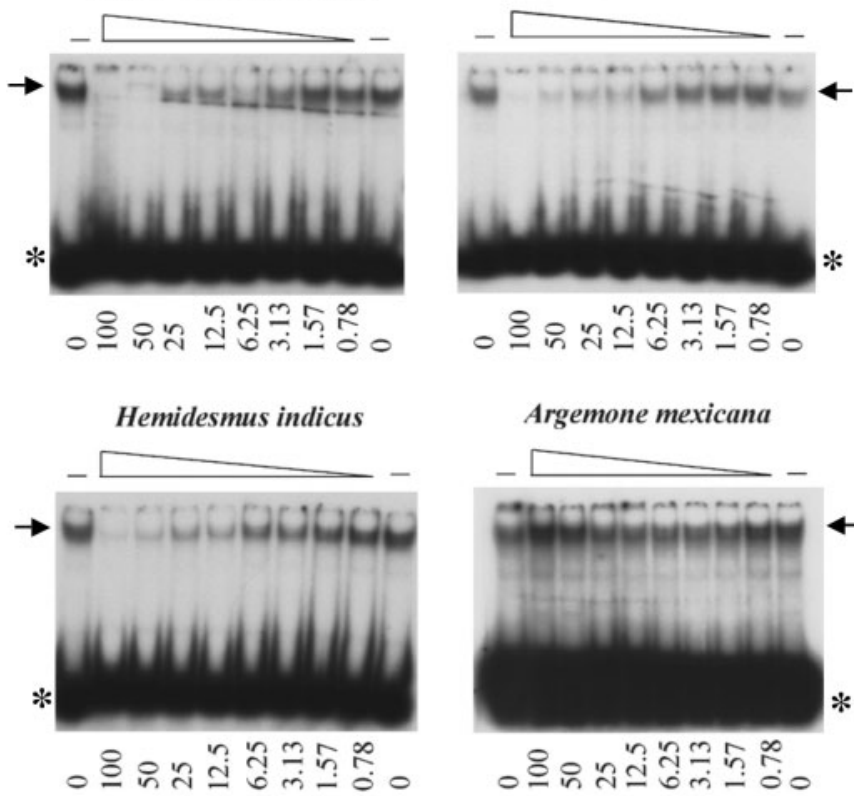

Argemone mexicana

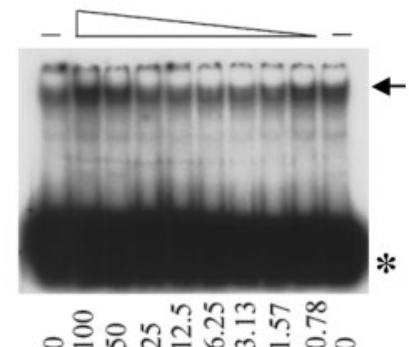

$\mu \mathrm{g} / \mathrm{binding}$ reaction

Figure 4. Extracts from medicinal plants differentially inhibit molecular interactions between NF-kB and target DNA sequences. The effects on NF-kB/DNA interactions of the indicated amounts of extracts from A. marmelos, P. longifolia, L. speciosa, $V$. anthelmintica, $H$. indicus and A. mexicana are reported. For description of the technical detail, see legend to Fig. $3 .{ }^{*}=$ free probe; arrows $=$ NF-kB/DNA complexes.

$O$. sanctum and $A$. polystachya oil fraction were still unable to inhibit GATA-1/DNA interactions.

As far as STAT-3/DNA interaction, in addition to $T$. arjuna extracts the aqueous fraction of $R$. maritimus, $S$. asoka and solid fraction of $A$. polystachya extracts were also inhibitory (Fig. 6A), while only $75 \mu \mathrm{g} /$ binding reaction of ethyl acetate fraction of $A$. marmelos and $O$. sanctum extracts displayed inhibitory activity. The remaining extracts were not capable of any activity.

Finally, regarding the CREB/DNA interaction studies, Table 3 and the related Fig. 6B show that, in addition to $T$. arjuna extracts, only those from $S$. asoka and E. officinalis possess an intermediate activity, whereas the other medicinal plant extracts are completely inactive. 

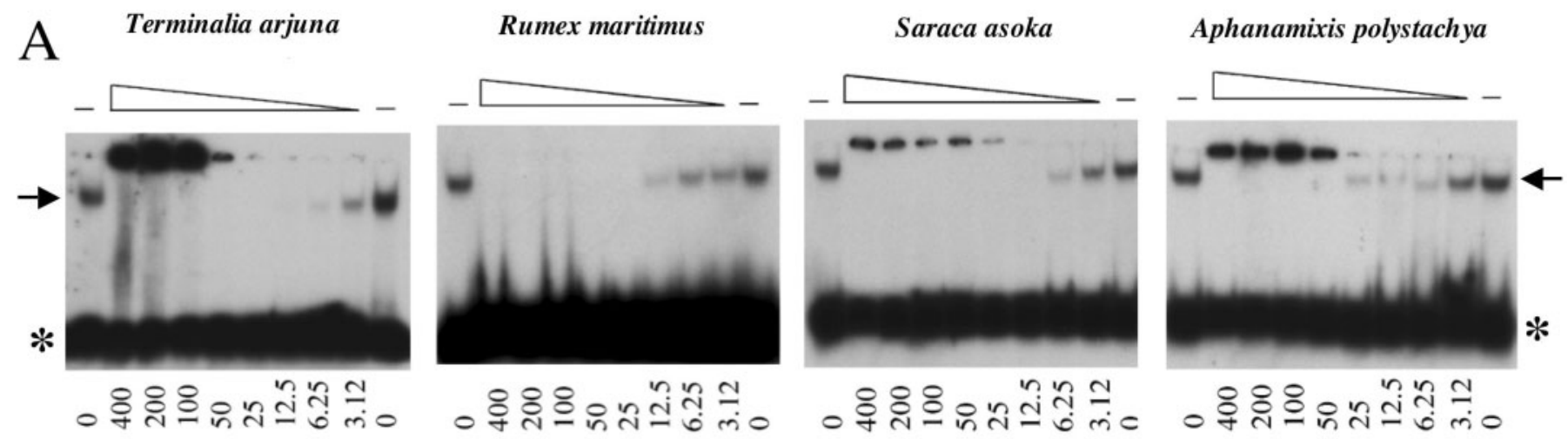

$\mu \mathrm{g} / \mathrm{binding}$ reaction
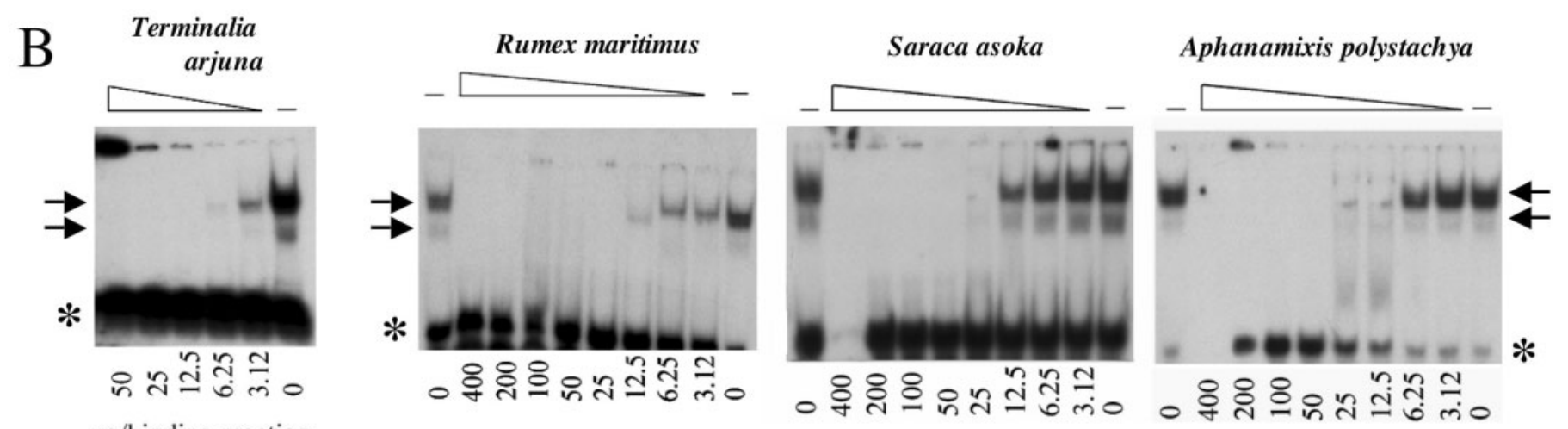

Figure 5. Extracts from medicinal plants inhibiting molecular interactions between AP-1 (A) and GATA-1 (B) TFs and target DNA sequences. The effects of the indicated amounts of extracts from T. arjuna, R. maritimus, S. asoka and A. polystachya were studied on AP-1/DNA (A) and GATA-1/ DNA (B) interactions. For description of the technical detail, see legend to Figure $3 .{ }^{*}=$ free probe; arrows $=$ protein/DNA complexes.

\section{Discussion}

Inhibition of DNA-protein interactions could be a very promising strategy for the development of antitumor and antiviral therapeutic agents, as well as for the intervention in other different human pathologies related to inflammation, such as rheumatoid arthritis, chronic asthma and inflammatory bowel diseases (22-26).

DNA-binding drugs are extremely relevant and are the object of numerous research articles. Consistent results by our team and other research groups demonstrated that DNA-binding drugs inhibit the molecular interactions between DNA and TFs, leading to alteration of transcription (51-56). To analyze the possible interactions between TFs and the specific DNA elements we employed the EMSA for all preliminary experiments. In this context, several plant extracts were described able to inhibit DNA-protein interactions, and they may be a possible source of lead compounds that can alter gene expression.

The aim of this study was to screen several plant extracts for their ability to inhibit molecular interactions between DNA and TFs involved in the process of inflammation, including NF-kB, AP-1, STATs, CREB and GATA-1. Natural products derived from medicinal plants might play an interesting role for the identification of novel drugs for treating several diseases and they represent an important alternative source (57) for molecules inhibiting NF-kB activity.

For example, utilizing macrophages transfected with a vector coding for the luciferase reporter gene under the control of NF-kB cis-acting elements, investigators demonstrated that LPS (LipoPolySaccharide)-stimulated luciferase activity was affected by adding of extracts from the medicinal plant Glossogyne tenuifolia, utilized in Chinese medicine as a traditional antipyretic herb (58). Accordingly G. tenuifolia attenuates inflammatory mediator synthesis of activated macrophages through an NF-kB-dependent pathway. Moreover, the identified oleanolic acid and luteolin-7-glucoside, present in the extracts derived from this medicinal plant, inhibited LPS-stimulated inflammatory mediator production and NF-kB activation (58).

A second example is related to recent studies demonstrating that garcinol, a polyisoprenylated benzophenone derived from another medicinal plant, Garcinia indica, exhibits antioxidative effects in vitro. Liao et al. (59) 


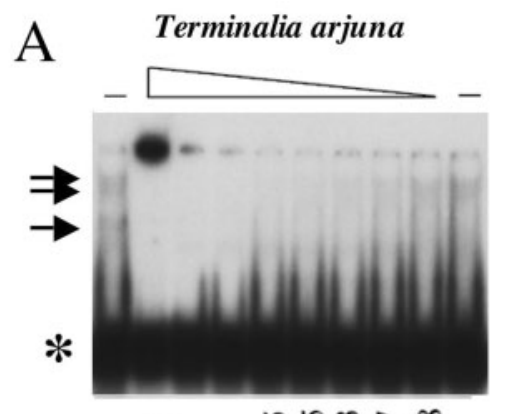

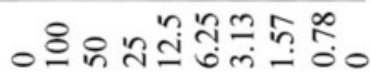

$\mu \mathrm{g} /$ binding reaction

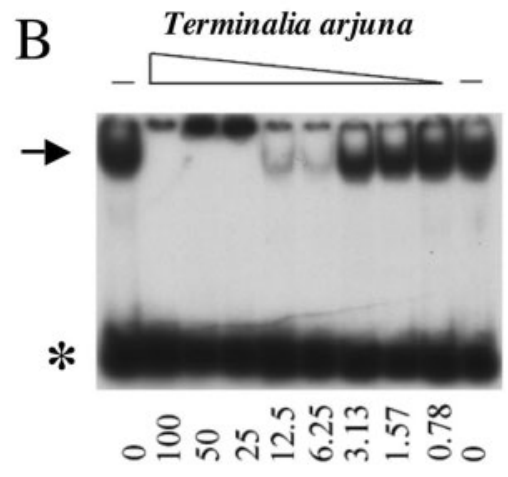

$\mu \mathrm{g} /$ binding reaction

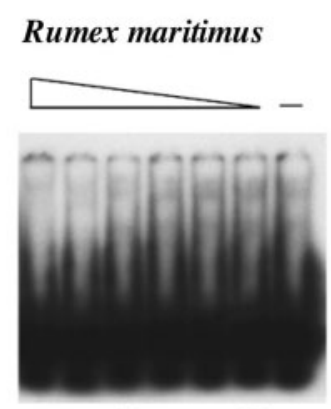

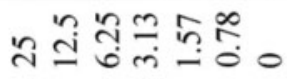

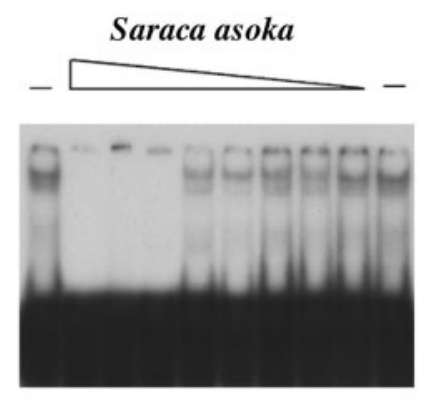

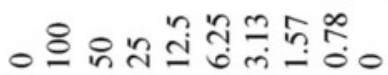

Aphanamixis polystachya

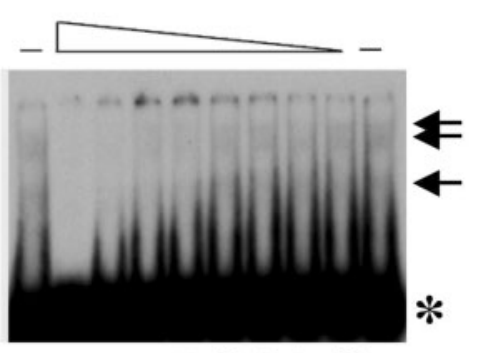

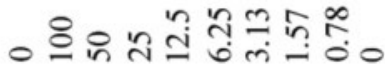

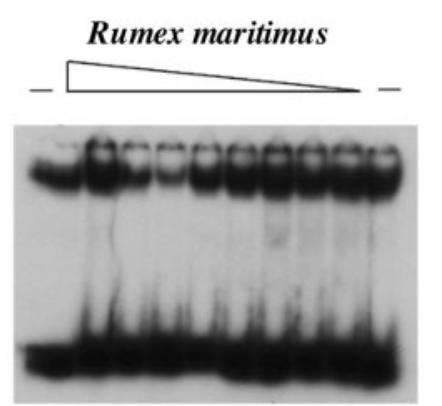

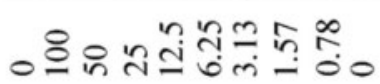
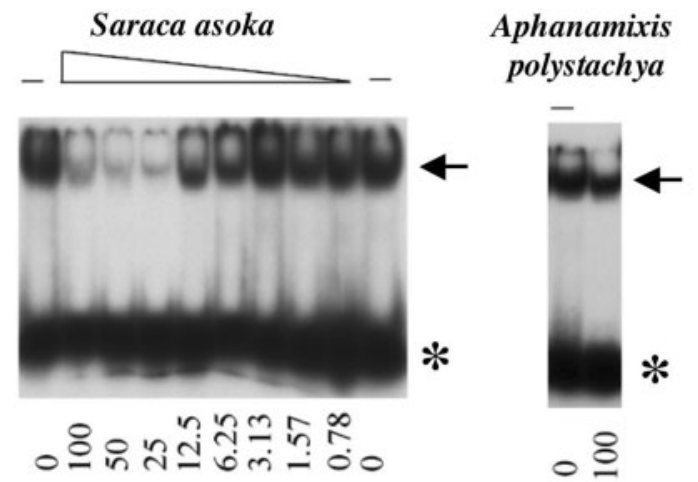

Figure 6. Extracts from medicinal plants inhibiting molecular interactions between STAT-3 (A) and CREB (B) and target DNA sequences. The effects of the indicated amounts of extracts from T. arjuna, R. maritimus, S. asoka and A. polystachya were studied on STAT-3/DNA (A) and CREB/ DNA (B) interactions. For description of the technical detail, see legend to Fig. $3 .{ }^{*}=$ free probe; arrows $=$ protein/DNA complexes.

demonstrated with western blot analysis and gel-shift assays (EMSA) that garcinol strongly blocks the activation of eukaryotic TF NF-kB-induced by LPS. Moreover, for instance, transient transfection experiments showed that garcinol inhibited the NF-kB-dependent transcriptional activity.

The main conclusion of the present article is that inhibitory activity against TFs is displayed by several plant extracts, as shown in Table 3 , in which the $\mathrm{IC}_{50}$ values (concentration leading to $50 \%$ inhibition of TFs/ DNA interactions) of the electrophoretic mobility shift assays are summarized. The data suggest that $P$. longifolia represents an extract displaying interesting selectivity in inhibiting only the NF-kB/DNA interaction, whereas for example $T$. arjuna demonstrated a very high activity in all TFs/DNA binding experiments. Both extracts derived from $E$. officinalis interfered preferentially with NF-kB/DNA interaction with lower selectivity than $P$. longifolia, while only one fraction of $A$. marmelos (pet. ether extract) was selective for GATA-1/DNA interaction. Hemidesmus indicus also appears to be an interesting selective extract, since it inhibits NF-kB/DNA interaction at $12 \mu \mathrm{g} / \mathrm{ml}$, while it is active on the other
TF/DNA interactions only when added at $50 \mu \mathrm{g} / \mathrm{ml}$ or higher concentrations.

Both $A$. polystachya fractions proved a high, but not selective, activity particularly on the inhibition of $\mathrm{NF}-\mathrm{kB} /$ DNA interactions. Moringa oleifera and L. speciosa extracts were active on NF-kB, AP-1 and GATA-1 and inactive on other TFs. Vernonia anthelmintica demonstrated activity with NF-kB and GATA-1 only. Saraca asoka inhibited all TFs/DNA interactions even if at different concentrations. The aqueous fraction of $R$. maritimus was more active in inhibiting NF-kB, AP-1, GATA-1 and STAT-3 interactions than the methanolic extract, which interfered at intermediate concentrations with NF-kB/DNA interaction only. Ocimum sanctum was the only extract that selectively inhibited the STAT-3/ DNA interaction. Finally, the remaining medicinal plant extracts were ineffective on all protein/DNA interactions.

These data support the concept that medicinal plant extracts represent a potential source of compounds exhibiting the ability to suppress the molecular interactions between TFs and target DNA sequences. Further experiments [Gas Chromatography/Mass Spectrometry (GC/ MS), High-Performance Liquid Chromatography/Mass 
Table 3. Inhibitory effects of plant extracts on the interactions between nuclear factors and double stranded synthetic oligonucleotides mimicking the binding sites of the NF-kB, AP-1, GATA-1, STAT-3 and CREB trascription factors

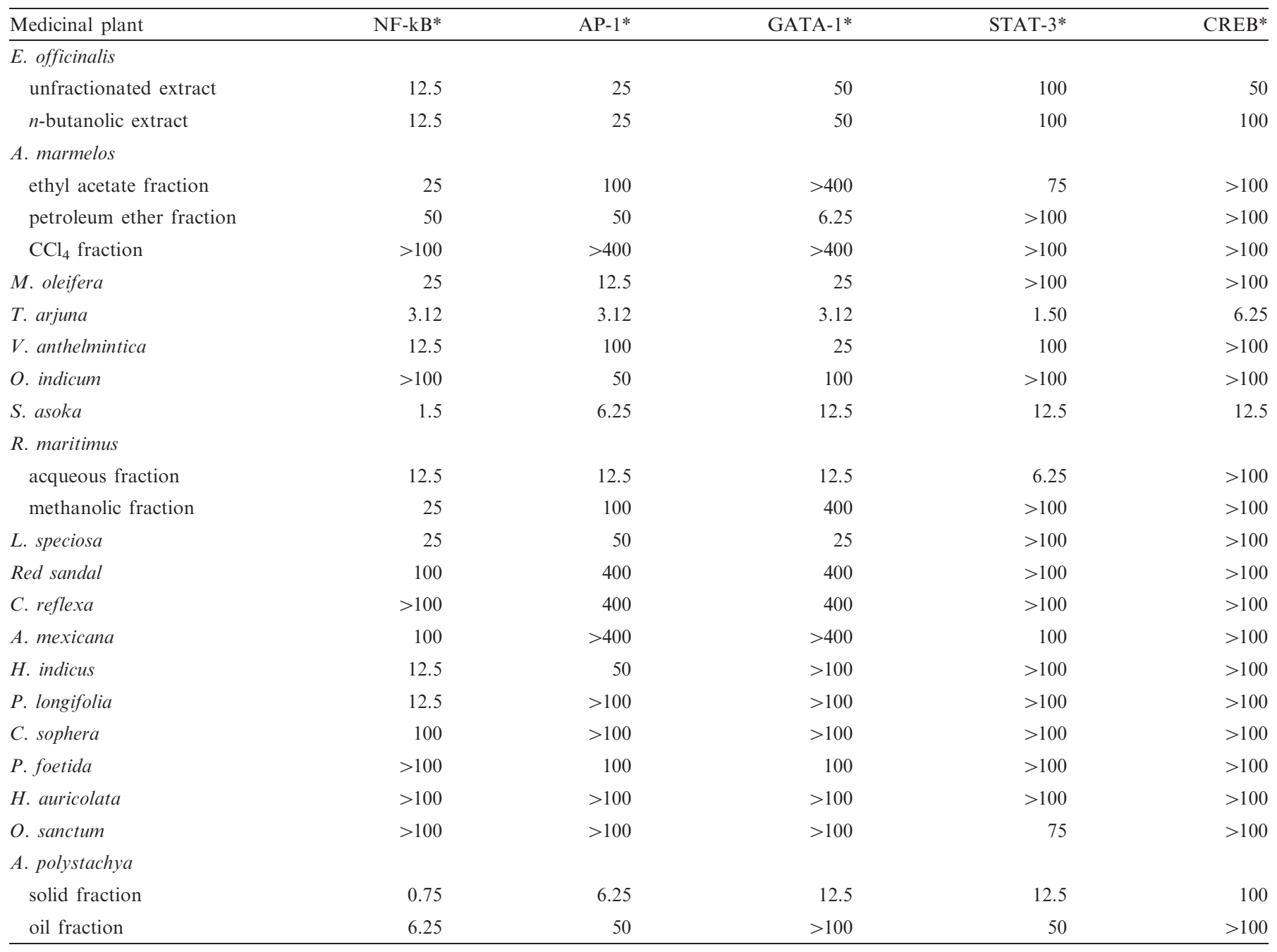

*Concentrations are expressed in $\mu \mathrm{g} /$ binding reaction $(20 \mu \mathrm{l})$. The data reported represent the concentrations of plant extracts leading to a $50 \%$ inhibition of protein/DNA interactions.

Spectrometry (LC/MS)] should be performed to identify pure compounds exhibiting these activities. However, it should be pointed out that several compounds have already been described in plant extracts analyzed in the present article. For instance, three thiocarbamate (TC)- and isothiocyanate (ITC)-related compounds have been isolated from the leaves of $M$. oleifera (60). In addition, the oleanane triterpenes arjunic acid, arjungenin and their glucosides, arjunetin and arjunglucoside II, were isolated from the bark of $T$. arjuna (61). Several flavonoids including 2',3,4,4'-tetrahydroxychalcone, 5,6,7,4'-tetrahydroxyflavone and butin, were separated from the seeds of $V$. anthelmintica (62). The leaves of $L$. speciosa afforded a new natural product, 31-norlargerenol acetate, along with known compounds 24-methylenecycloartanol acetate, its 31-nor analog, largerenol acetate, tinotufolins C and D, lutein, phytol, sitosterol and sitosterol acetate (63). Pyrogallol was identified in extracts from $E$. officinalis (35).
Therefore, EMSA analysis of the activity of the compounds already demonstrated to be present in the plant extracts exhibiting inhibitory activity on TF/DNA interactions is expected to help in identifying the molecules responsible for the activity of the plant extracts.

As far as the possible relationships between effects on cell growth and effects on protein-DNA interactions, when data from Tables 1-3 are compared, evidently some extracts, including for example $O$. indicus, E. officinalis, T. arjuna and A. marmelos (petroleum ether fraction), inhibit TFs/DNA interactions and are also highly effective in inhibiting cell proliferation. This is expected, considering the relevant involvement of TFs on cell cycle progression. On the contrary, other extracts, even inhibiting protein/DNA interactions, do not display antiproliferative activity.

Therefore, our study suggests that medicinal plant extracts exhibiting inhibitory activity on cell proliferation 
should undergo analysis for possible antitumor activity, while extracts displaying inhibition of TFs/DNA interactions without effects on cell growth kinetics might be employed to control TFs-dependent gene expression without cytotoxic effects, including the case of inflammatory processes involved in relevant human pathologies, such as rheumatoid arthritis and cystic fibrosis.

\section{Acknowledgements}

This work is funded by CIB (Consorzio Interuniversitario di Biotecnologie, Italy), AVLT (Associazione Veneta per la Lotta alla Talassemia, Italy), SPINNER e PRIITT (EU, Obiettivo 2), Fondazione Cassa di Risparmio di Padova e Rovigo, Fondazione Italiana per la Fibrosi Cistica, STAMINA Project of Ferrara University and UE ITHANET Project.

\section{References}

1. Ji H, Wong WH. Computational biology: toward deciphering gene regulatory information in mammalian genomes. Biometrics 2006:62:645-63.

2. Penolazzi L, Magri E, Lambertini E, Calo G, Cozzani M, Siciliani G, et al. Local in vivo administration of a decoy oligonucleotide targeting NF-kappaB induces apoptosis of osteoclasts after application of orthodontic forces to rat teeth. Int $\mathrm{J} \mathrm{Mol}$ Med 2006;18:807-11.

3. Penolazzi L, Magri E, Lambertini E, Bianchini E, Piva R, Gambari R. "In vivo" local transfection of a cis element decoy mimicking an estrogen receptor alpha gene promoter region induces apoptosis of osteoclasts following application of orthodontic forces to rat teeth. Apoptosis 2006;11:1653-6.

4. Chiarabelli C, Bianchi N, Borgatti M, Prus E, Fibach E, Gambari R. Induction of gamma-globin gene expression by tallimustine analogs in human erythroid cells. Haematologica 2003;88:826-7.

5. Fibach E, Bianchi N, Borgatti M, Prus E, Gambari R. Mithramycin induces fetal hemoglobin production in normal and thalassemic human erythroid precursor cells. Blood 2003;102:1276-81.

6. Mann MJ, Dzau VJ. Therapeutic applications of transcription factor decoy oligonucleotides. J Clin Invest 2000;106:1071-5.

7. Karkare S, Bhatnagar D. Promising nucleic acid analogs and mimics: characteristic features and applications of PNA, LNA, and morpholino. Appl Microbiol Biotechnol 2006;71:575-86.

8. Borgatti M, Finotti A, Romanelli A, Saviano M, Bianchi N, Lampronti I, et al. Peptide nucleic acids (PNA)-DNA chimeras targeting transcription factors as a tool to modify gene expression. Curr Drug Targets 2004;5:735-44.

9. Sebban H, Courtois G. NF-kappaB and inflammation in genetic disease. Biochem Pharmacol 2006;72:1153-60.

10. Hayden MS, Ghosh S. Signaling to NF-kB. Genes Dev 2004;18:2195-224.

11. Chen F, Demers LM, Shi X. Upstream signal transduction of NF-kappaB activation. Curr Drug Targets Inflamm Allergy 2002;1:137-49.

12. Monteleone G, Mann J, Monteleone I, Vavassori P, Bremner R, Fantini M, et al. A failure of TGFbeta 1 negative regulation maintains sustained NF-KB activation in gut inflammation. $J$ Biol Chem 2004;279:3925-32.

13. Liao CH, Sang S, Liang YC, Ho CT, Lin JK. Suppression of inducible nitric oxide synthase and cyclooxygenase-2 in downregulating nuclear factor-kappaB pathway by Garcinol. Mol Carcinog 2004;41:140-9.

14. Loncar MB, Al-azzeh ED, Sommer PS, Marinovic M, Schmehl K, Kruschewski $\mathrm{M}$, et al. Tumour necrosis factor alpha and nuclear factor kappaB inhibit transcription of human TFF3 encoding a gastrointestinal healing peptide. Gut 2003;52:1297-303.
15. Wagner EF, Eferl R. Fos/AP-1 proteins in bone and the immune system. Immunol Rev 2005;208:126-40.

16. Yoshimura A, Mori H, Ohishi M, Aki D, Hanada T. Negative regulation of cytokine signaling influences inflammation. Curr Opin Immunol 2003;15:704-8.

17. Hanada T, Yoshimura A. Regulation of cytokine signaling and inflammation. Cytokine Growth Factor Rev 2002;13:413-21.

18. Hodge DR, Hurt EM, Farrar WL. The role of IL-6 and STAT3 in inflammation and cancer. Eur J Cancer 2005;41:2502-12.

19. Nakajima T, Aratani S, Nakazawa M, Hirose T, Fujita H, Nishioka K. Implications of transcriptional coactivator CREB binding protein complexes in rheumatoid arthritis. Mod Rheumatol 2004;14:6-11.

20. Masuda A, Yoshikai Y, Kume H, Matsuguchi T. The interaction between GATA proteins and activator protein-1 promotes the transcription of IL-13 in mast cells. J Immunol 2004;173:5564-73.

21. Hirasawa R, Shimizu R, Takahashi S, Osawa M, Takayanagi S, Kato $\mathrm{Y}$, et al. Essential and instructive roles of GATA factors in eosinophil development. J Exp Med 2002;195:1379-86.

22. Sato K, Takayanagi H. Osteoclasts, rheumatoid arthritis, and osteoimmunology. Curr Opin Rheumatol 2006;18:419-26.

23. Nozaki K, Hikiami H, Goto H, Nakagawa T, Shibahara N, Shimada Y. Keishibukuryogan (Gui-Zhi-Fu-Ling-Wan), a Kampo Formula, Decreases Disease Activity and Soluble Vascular Adhesion Molecule-1 in Patients with Rheumatoid Arthritis. Evid Based Complement Alternat Med 2006;3:359-64.

24. Adcock IM, Ito K, Barnes PJ. Histone deacetylation: an important mechanism in inflammatory lung diseases. COPD 2005;2:445-55.

25. Blease K, Lewis A, Raymon HK. Emerging treatments for asthma. Expert Opin Emerg Drug 2003;8:71-81.

26. Gray SG, De Meyts P. Role of histone and transcription factor acetylation in diabetes pathogenesis. Diabetes Metab Res Rev 2005;21:416-33.

27. Stucchi A, Reed K, O'Brien M, Cerda S, Andrews C, Gower A, et al. A new transcription factor that regulates TNF-alpha gene expression, LITAF, is increased in intestinal tissues from patients with CD and UC. Inflamm Bowel Dis 2006;12:581-7.

28. Tohda C, Nakayama N, Hatanaka F, Komatsu K. Comparison of Anti-inflammatory Activities of Six Curcuma Rhizomes: a Possible Curcuminoid-independent Pathway Mediated by Curcuma phaeocaulis Extract. Evid Based Complement Alternat Med 2006;3:255-60.

29. Wu MJ, Wang L, Ding HY, Weng CY, Yen JH. Glossogyne tenuifolia acts to inhibit inflammatory mediator production in a macrophage cell line by downregulating LPS-induced NF-kappaB. J Biomed Sci 2004;11:186-99.

30. Ahmed S, Anuntiyo J, Malemud CJ, Haqqi TM. Biological basis for the use of botanicals in osteoarthritis and rheumatoid arthritis: a review. Evid Based Complement Alternat Med 2005;2:301-8.

31. Salem ML. Immunomodulatory and therapeutic properties of the Nigella sativa L. seed. Int Immunopharmacol 2005;5:1749-70.

32. Fylaktakidou KC, Hadjipavlou-Litina DJ, Litinas KE, Nicolaides DN. Natural and synthetic coumarin derivatives with anti-inflammatory/antioxidant activities. Curr Pharm Des 2004;10:3813-33.

33. Nozaki K, Hikiami H, Goto H, Nakagawa T, Shibahara N, Shimada Y. Keishibukuryogan (gui-zhi-fu-ling-wan), a kampo formula, decreases disease activity and soluble vascular adhesion molecule-1 in patients with rheumatoid arthritis. Evid Based Complement Alternat Med 2006;3:359-64.

34. Saad B, Azaizeh H, Said O. Tradition and perspectives of arab herbal medicine: a review. Evid Based Complement Alternat Med 2005;2:475-9.

35. Khan MT, Lampronti I, Martello D, Bianchi N, Jabbar S, Choudhuri MS, et al. Identification of pyrogallol as an antiproliferative compound present in extracts from the medicinal plant Emblica officinalis: effects on in vitro cell growth of human tumor cell lines. Int $J$ Oncol 2002;21:187-92.

36. Luo JZ, Luo L. American ginseng stimulates insulin production and prevents poptosis through egulation of uncoupling protein-2 in cultured beta Cells. Evid Based Complement Alternat Med 2006;3:365-72.

37. Lampronti I, Martello D, Bianchi N, Borgatti M, Lambertini E, Piva R, et al. In vitro antiproliferative effects on human tumor cell 
lines of extracts from the Bangladeshi medicinal plant Aegle marmelos Correa. Phytomedicine 2003;10:300-8.

38. Jagetia GC, Rao SK. Evaluation of cytotoxic effects of Dichloromethane extract of Guduchi (Tinospora cordifolia Miers ex Hook F \& THOMS) on cultured HeLa cells. Evid Based Complement Alternat Med 2006;3:267-72.

39. Lambertini E, Piva R, Khan MT, Lampronti I, Bianchi N, Borgatti M, et al. Effects of extracts from Bangladeshi medicinal plants on in vitro proliferation of human breast cancer cell lines and expression of estrogen receptor alpha gene. Int $J$ Oncol 2004;24:419-23.

40. Adams LS, Seeram NP, Hardy ML, Carpenter C, Heber D. Analysis of the interactions of botanical extract combinations against the viability of prostate cancer cell lines. Evid Based Complement Alternat Med 2006;3:117-24.

41. Chui CH, Lau FY, Tang JC, Kan KL, Cheng GY, Wong RS, et al. Activities of fresh juice of Scutellaria barbata and warmed water extract of Radix Sophorae Tonkinensis on anti-proliferation and apoptosis of human cancer cell lines. Int $J \mathrm{Mol} \mathrm{Med}$ 2005;16:337-41.

42. Lau FY, Chui CH, Gambari R, Kok SH, Kan KL, Cheng GY, et al. Antiproliferative and apoptosis-inducing activity of Brucea javanica extract on human carcinoma cells. Int $J \mathrm{Mol} \mathrm{Med}$ 2005; 16:1157-62.

43. Xie F, Wu CF, Lai WP, Yang XJ, Cheung PY, Yao XS, et al. The osteoprotective effect of Herba epimedii (HEP) extract in vivo and in vitro. Evid Based Complement Alternat Med 2005;2:353-61.

44. Lampronti I, Saab AM, Gambari R. Antiproliferative activity of essential oils derived from plants belonging to the Magnoliophyta division. Int J Oncol 2006;29:989-95.

45. Lampronti I, Khan MTH, Bianchi N, Borgatti M, Gambari R. Inhibitory effects of medicinal plant extracts on interactions between DNA and trancription factors involved in inflammation. Minerva Biotecnologica 2004;16:93-9.

46. Lampronti I, Khan MTH, Bianchi N, Ather A, Borgatti M, Vizziello L, et al. Bangladeshi medicinal plant extracts inhibiting molecular interactions between nuclear factors and target DNA sequences mimicking NF-kappaB binding sites. Med Chem 2005;1:327-33.

47. Borgatti M, Lampronti I, Romanelli A, Pedone C, Saviano M, Bianchi N, et al. Transcription factor decoy molecules based on a peptide nucleic acid (PNA)-DNA chimera mimicking Sp1 binding sites. J Biol Chem 2003;278:7500-9.

48. Bianchi N, Chiarabelli C, Borgatti M, Mischiati C, Fibach E, Gambari R. Accumulation of gamma-globin mRNA and induction of erythroid differentiation after treatment of human leukaemic K562 cells with tallimustine. $\mathrm{Br} \quad J$ Haematol 2001:113:951-61.

49. Drexler HG, Minowada J. History and classification of humanlymphoma cell lines. Leuk Lymphoma 1998;31:305-16.
50. Ganes S, Anel A, Lasierra P, Alava MA, Martinez-Lorenzo MJ, Piniero A, et al. Doxorubicin-induced apoptosis in human T-cell leukemia is mediated by caspase-3 activation in a Fas-independent way. FEBS Lett 1997;417:360-4.

51. Gambari R. New trends for the development of novel decoy molecules against nuclear factor kappa-B (NF-kB) transcription factor. Minerva Biotecnologica 2004;16:145-9.

52. Piva R, Penolazzi L, Lambertini E, Giordano S, Gambari R. Induction of apoptosis of human primary osteoclasts treated with a transcription factor decoy mimicking a promoter region of estrogen receptor alpha. Apoptosis 2005;10:1079-94.

53. Agarwal N, Gewirtz AM. Oligonucleotide therapeutics for hematologic disorders. Biochim Biophys Acta 1999;1489:85.

54. Praseuth D, Guieysse AL, Helene C. Triple helix formation and the antigene strategy for sequence-specific control of gene expression. Biochim Biophys Acta 1999;1489:181-206.

55. Gorman L, Glazer PM. Directed gene modification via triple helix formation. Curr Mol Med 2001;1:391-9.

56. Bianchi N, Chiarabelli C, Borgatti M, Mischiati C, Fibach E, Gambari R. Accumulation of gamma-globin mRNA and induction of erythroid differentiation after treatment of human leukaemic K562 cells with tallimustine. $B r \quad J$ Haematol 2001:113:951-61.

57. Heinrich M, Gibbons S. Ethnopharmacology in drug discovery: an analysis of its role and potential contribution. J Pharm Pharmacol 2001;53:425-32.

58. Wu MJ, Wang L, Ding HY, Weng CY, Yen JH. Glossogyne tenuifolia acts to inhibit inflammatory mediator production in a macrophage cell line by downregulating LPS-induced NF-kappaB. J Biomed Sci 2004;11:186-99.

59. Liao CH, Sang S, Liang YC, Ho CT, Lin JK. Suppression of inducible nitric oxide synthase and cyclooxygenase-2 in downregulating nuclear factor-kappaB pathway by Garcinol. Mol Carcinog 2004:41:140-9.

60. Murakami A, Kitazono Y, Jiwajinda S, Koshimizu K, Ohigashi H. Niaziminin, a thiocarbamate from the leaves of Moringa oleifera, holds a strict structural requirement for inhibition of tumor-promoter-induced Epstein-Barr virus activation. Planta Med 1998;64:319-23.

61. Pawar RS, Bhutani KK. Effect of oleanane triterpenoids from Terminalia arjuna -a cardioprotective drug on the process of respiratory oxyburst. Phytomedicine 2005;12:391-3.

62. Tian G, Zhang U, Zhang T, Yang F, Ito Y. Separation of flavonoids from the seeds of Vernonia anthelmintica Willd by high-speed counter-current chromatography. $J$ Chromatogr $A$ 2004;1049:219-22.

63. Ragasa CY, Ngo HT, Rideout JA. Terpenoids and sterols from Lagerstroemia speciosa. J Asian Nat Prod Res 2005;7:7-12.

Received November 24, 2006; accepted March 14, 2007 


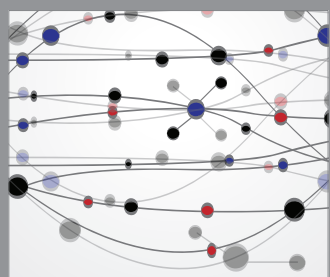

The Scientific World Journal
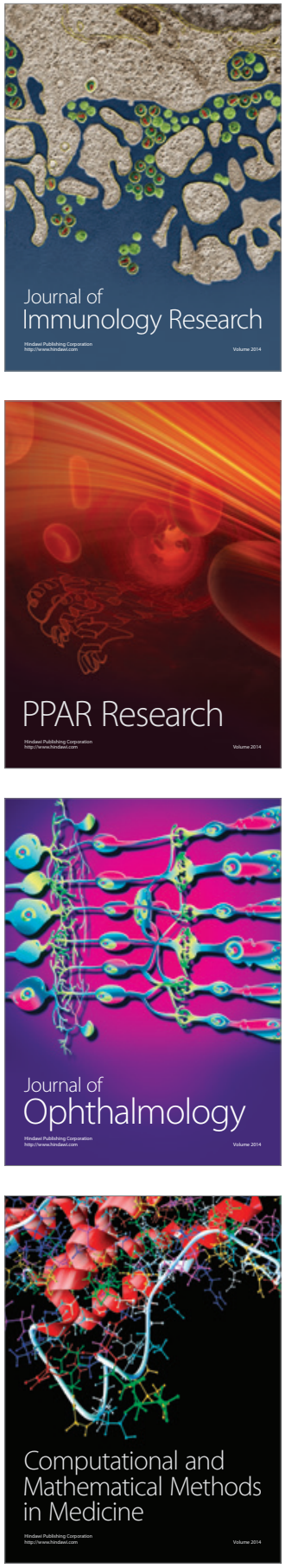

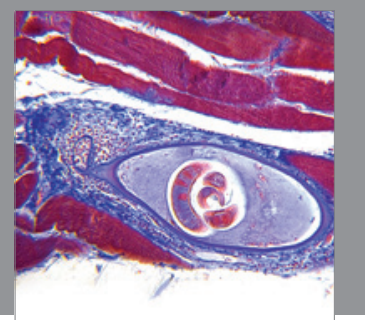

Gastroenterology

Research and Practice
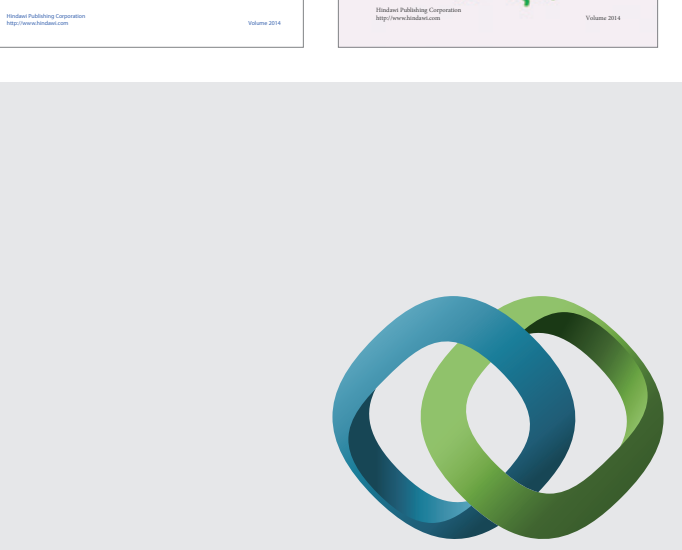

\section{Hindawi}

Submit your manuscripts at

http://www.hindawi.com
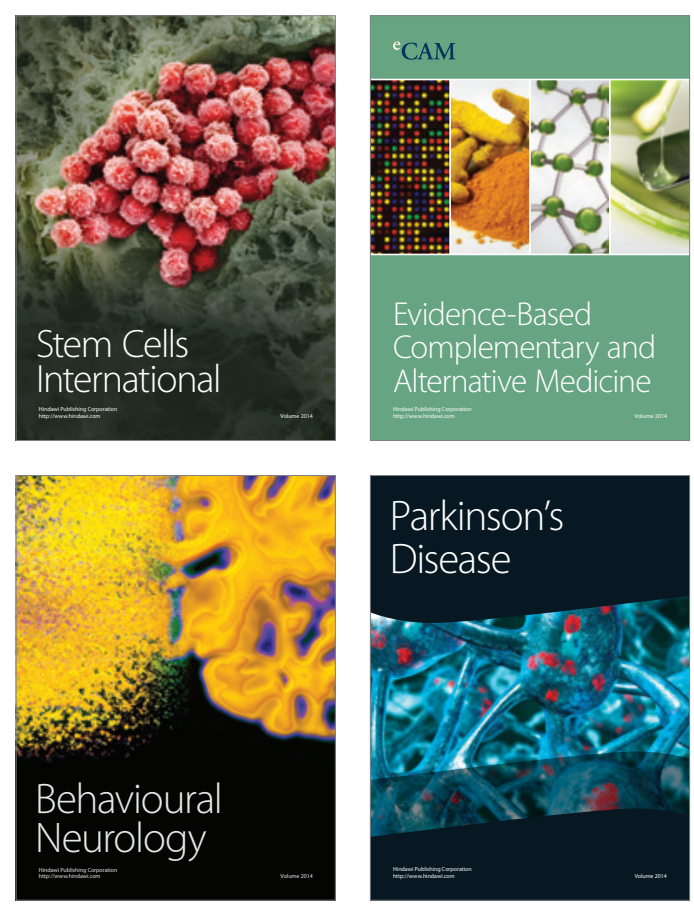

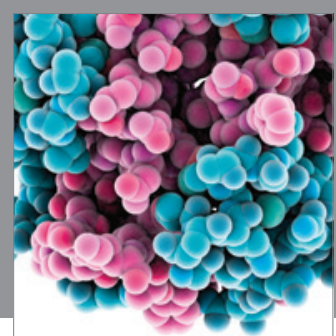

Journal of
Diabetes Research

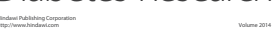

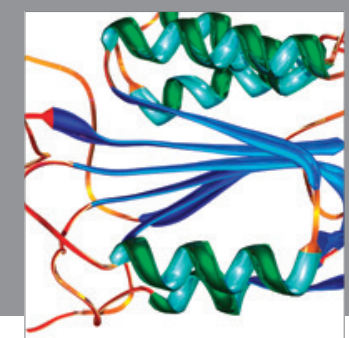

Disease Markers
